WSRC-TR--92-466

DE93 003310

\title{
ALTERNATIVE DESIGN CONCEPT FOR THE SECOND GLASS WASTE STORAGE BUILDING (U)
}

by R. Rainisch

Westinghouse Savannah River Company

Savannah River Site

Aiken, South Carolina 29808

Other Authors: $N / A$

This paper was prepared in connection with work done under Contract No. DE-AC09-89SR18035 with the U.S. Department of Energy. By acceptance of this paper, the publisher and/or recipient acknowledges the U.S. Government's right to retain a nonexclusive, royalty-free license in and to any copyright covering this paper, along with the right to reproduce and to authorize others to reproduce all or part of the copyrighted paper.

\section{MASTER}




\section{DISCLAIMER}

This report was prepared as an account of work sponsored by an agency of the United States Government. Neither the United States Government nor any agency thereof, nor any of their employees, makes any warranty, express or implied, or assumes any legal liability or responsibility for the accuracy, completeness, or usefulness of any information, apparatus, product, or process disclosed, or represents that its use would not infringe privately owned rights. Reference herein to any specific commercial product, process, or service by trade name, trademark, manufacturer, or otherwise does not necessarily constitute or imply its endorsement, recommendation, or favoring by the United States Government or any agency thereof. The views and opinions of authors expressed herein do not necessarily state or reflect those of the United States Government or any agency thereof.

This report has been reproduced directly from the best available copy.

Available to DOE and DOE contractors from the Office of Scientific and Technical Information, P.O. Box 62, Oak Ridge, TN 37831; prices available from (615) 576-8401, FTS 626-8401.

Avaiiable to the public from the National Technical Information Service, U.S. Department of Commerce, 5285 Port Royal Rd., Springfield, VA 22161. 


\section{ALTERNATIVE DESIGN CONCEPT FOR THE}

SECOND GLASS WASTE STORAGE BUILDING (U)

R. Rainisch

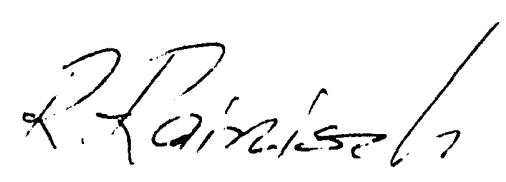

Publication Date: October 1992

Systems Engineering Department

Westinghouse Savannah River Company

Savannah River Site

Aiken, SC 29808

Document : WSRC-TR-92-466

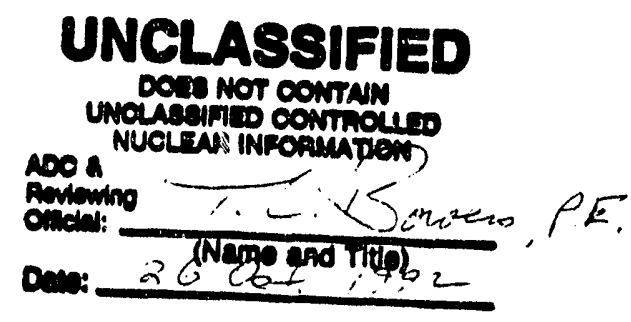




\section{CONTENTS}

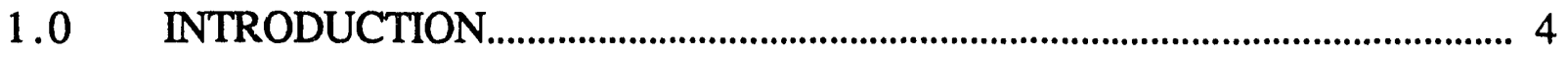

2.0 OUTLINE OF THE PROPOSED DESIGN ...................................................... 5

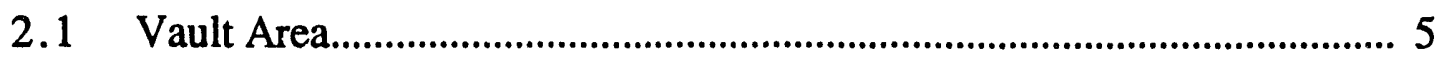

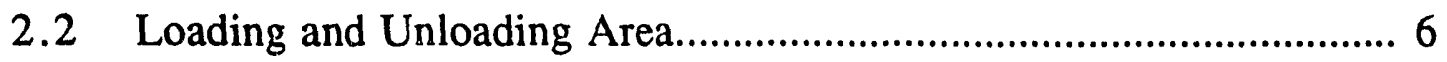

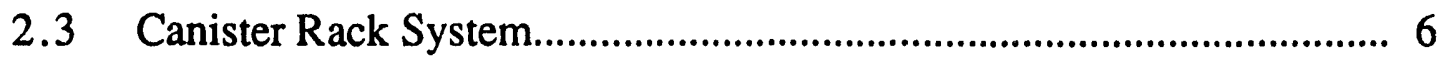

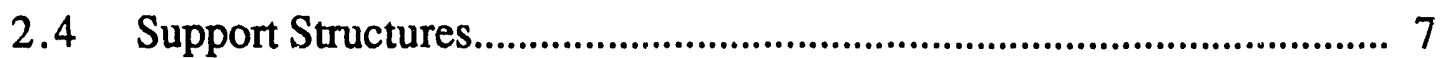

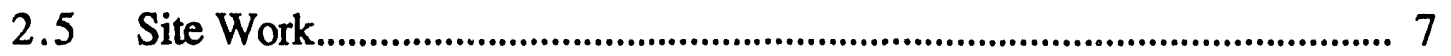

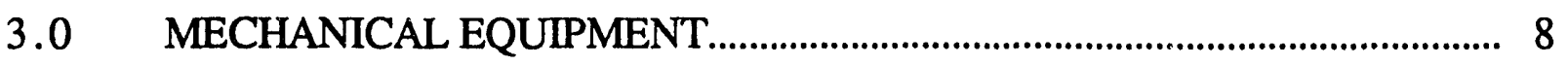

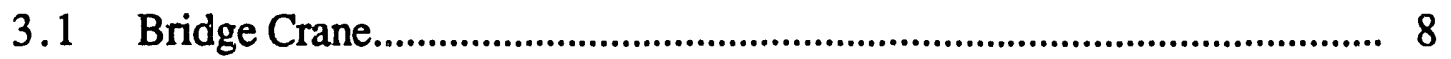

3.2 Transfer Tunnel Cars..................................................................... 9

3.3 Vault Cooling System.................................................................... 9

4.0 ELECTRICAL AND CONTROL EQUIPMENT............................................... 10

4.1 Electrical Requirements..................................................................... 10

4.2 Instrumentation and Control Requirements............................ 11

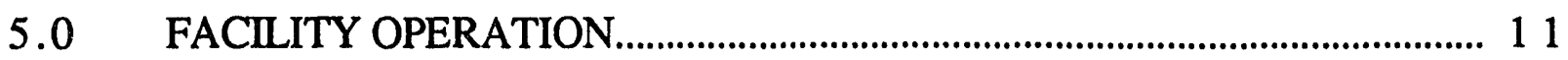

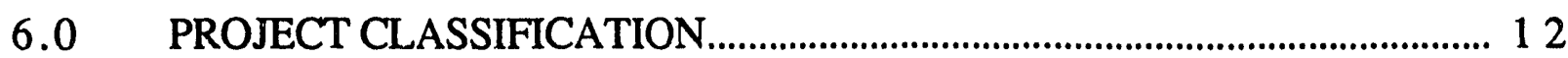

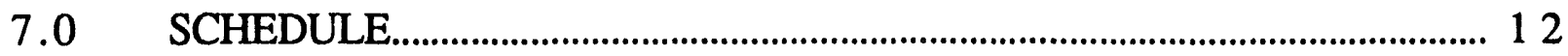

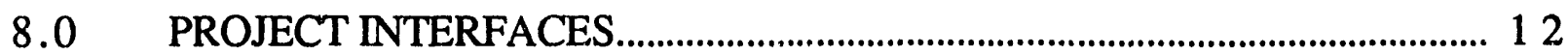

8.1 Glass Canisters............................................................................. 12

8.2 Shielded Canister Transporter.................................................. 12

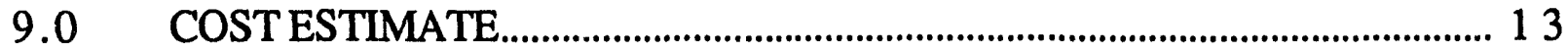

10.0 ASSESSMENT OF THE PROPOSED STORAGE SCHEME.............................. 14

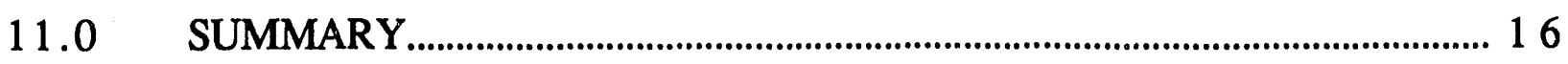

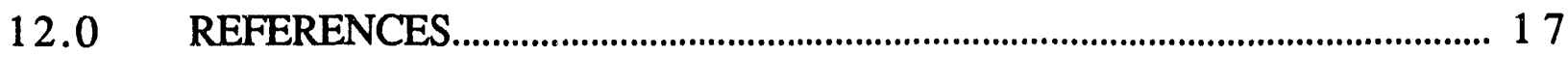




\section{LIST OF FIGURES}

1. Proposed Glass Waste Storage Building - Arrangement Plan View............ 18

2. Proposed Glass Waste Storage Building - Arrangement Section.................... 19

3. Proposed Glass Waste Storage Building - Vault Area Section........................ 20

4. Proposed Glass Waste Storage Building - Loading Area Longitudinal Section.............................................................................................. 21

5. Proposed Glass Waste Storage Building - Loading Area Cross Section................................................................................................................ 22

6. Proposed Glass Waste Storage Building - Plan View of Vault Compartment No. 1

\section{LIST OF TABLES}

9.1 Glass Waste Storage Facility Direct Cost Comparison Between The Proposed Design and the FDC/CDR Design (June 199i rates).............. 13 


\subsection{INTRODUCTION}

This document presents an alternative design concept for storing canisters filled with vitrified waste produced at the Defense Waste Processing Facility (DWPF). The existing Glass Waste Storage Building (GWSB1) has the capacity to store 2,262 canisters and is projected to be completely filled by the year 2000 . Current plans for glass waste storage are based on constructing a second Glass Waste Storage Building (GWSB2) once the existing Glass Waste Storage Building (GWSB1) is filled to capacity. The GWSB2 project (Project S-2045) is to provide additional storage capacity for 2,262 canisters. This project was initiated with the issue of a basic data report on March 6, 1989. In response to the basic data report Bechtel National, Inc. (BNI) prepared a draft conceptual design report (CDR) for the GWSB2 project in April 1991'1. In May 1991 WSRC Systems Engineering issued a revised Functional Design Criteria (FDC), the Rev. 1 document ${ }^{2}$ has not yet been approved by DOE.

This document proposes an alternative design for the conceptual design (CDR) completed in April 1991. An outline of the proposed storage concept was first prepared in October $1991^{3}$. In June 1992 Froject Management Department authorized Systems Engineering to further develop the proposed alternative design. Project Management instructed Systems Engineering to produce a more detailed cost estimate to facilitate selecting the more cost effective concept ${ }^{4}$. Like the FDC and CDR design, the alternative design is based on storing the glass canisters in a reinforced concrete vault and providing mechanically induced air cooling. However, a more compact storage scheme is proposed and canisters are stored and retrieved using a remotely operated bridge crane. The proposed facility will have a storage capacity for 2,268 canisters and will meet DWPF interim storage requirements for a five-year period.

This document contains: a description of the proposed facility; a cost estimate of the proposed design; a cost comparison between the proposed facility and the design outlined in the FDC/CDR; and an overall assessment of the alternative design as compared with the reference FDC/CDR design. 


\subsection{OUTLINE OF THE PROPOSED DESIGN}

The proposed facility can be located to the North of GWSB1 and will consist of one main structure and one support building. The main building is a reinforced concrete structure that includes: a storage vault; a loading and unloading area; and air inlet and outlet shafts. Overall dimensions of the main structure are $240 \mathrm{ft}$ by $58 \mathrm{ft}$ (see Figures 1 and 2). The support building is a steel-framed structure that houses the HVAC equipment.

\subsection{Vault Area}

The vault area is a partially below-grade reinforced concrete structure (see Figures 1 through 3). The vault floor is located $12 \mathrm{ft}$ below grade so that the floor in the adjacent loading area is at grade level. Inside dimensions of the vault are $173.5 \mathrm{ft} \mathrm{L} \times 51 \mathrm{ft} \mathrm{W} \times 46 \mathrm{ft} \mathrm{H}$. To satisfy shielding requirements, the vault's concrete walls are $3 \mathrm{ft} 6$ in. thick and the roof slab is $3 \mathrm{ft}$ thick. The selected shielding will reduce outside dose rates adjacent to the vault's wall to approximately $1 \mathrm{mR} /$ hour. The vault is subdivided into three compartments, and each compartment will be equipped with a rack system for locating and supporting the canisters. Air intake and outlet shafts constructed of reinforced concrete will provide the vault area with cooling air, as shown in Figures 1 and 3. The storage vaults, th. canister storage racks, and the bridge crane service and maintenance area will be safety class and will be designed for the design basis earthquake (DBE) and design basis tornado (DBT) accident scenarios.

Each compartment has a rack system for storing the glass canisters. The canisters are stored in two tiers. In each tier the canisters are arranged in an array of 21 rows, with 18 canisters in each row. Using a two tier arrangement provides for a storage capacity of 756 canisters per compartment and 2,268 canisters for the entire vault. The glos cylinders stand in their upright position on a center-to-center spacing of $30 \mathrm{in.} \mathrm{Because} \mathrm{the} \mathrm{canisters} \mathrm{are} 24 \mathrm{in}$. in diameter, 6 in. remains between canisters to accommodate the structural grid that accepts and supports the canisters. The 6-inch spacing will also be used for convective air currents for cooling the canisters.

A 20 ton overhead bridge crane is housed within the structure and is used to store and retrieve canisters. A mechanically induced air cooling system serving 
the vault area will remove decay heat and will ensure that the vault's air temperature remains within specified limits.

Subdividing the vault into compartments by use of internal shield walls has the following advantages:

- It renders a more flexible design, and will allow for multiple uses of the vault area.

- The shield walls reduce dose rates in areas designated for crane maintenance.

- Compartmentalization facilitates loading of glass canisters in a particular compartment without completely losing manned-entry to other compartments.

The design of the proposed facility is flexible and can be modified to increase the storage capacity by expanding the three compartments or by adding a compartment. The expansion would affect the vault design but would not have a significant impact on the loading area and support facilities design. Because the loading equipment and facilities can be shared, the incremental cost of additional canister storage positions is not excessive. Provisions for future expansion of the facility could be made if necessary.

\subsection{Loading and Unloading Area}

The filled canisters enter the facility through the loading and unloading area at one end of the storage vault. The loading and unloading area can also be designed as a staging area to ship canisters to an off site federal repository. Figures 1, 2, 4, and 5 provide an outline of this area. The dimensions of the loading and unloading area are $60 \mathrm{ft} \times 58 \mathrm{ft}$. The loading area incorporates: a transporter bay area with a $21-\mathrm{ft}$ high clearance for access to the shielded canister transporter (SCT); two redundant transfer tunnels with transfer cars to move canisters between the transporter bay and the vault area; a bridge crane manned-entry repair/service area; and an office enclosure that aiso houses a control room.

\subsection{Canister Rack System}

Each compartment will have a rack system to store the canisters. The rack system is comprised of unitized structural steel trusses. The truss units will be 
fabricated in an offsite facility, and later, assembled and connected inside the compartment. Each truss is approximately $7 \mathrm{ft} 7$ in. square and $19 \mathrm{ft} 6$ in. high and will support 18 canisters in a two-tier arrangement. The rack system in each of the compartments has 42 units. The rack system uses carbon structural tube steel 3 in. $x 3$ in. horizontally, and structural steel angles 4 in. $x 4$ in. posts to vertically support the canisters. The truss units will be placed inside the compartment and will be connected to other units by ASTM A325 structural bolts. The rack system will have lateral braces using 6-inch carbon structural steel channels to provide horizontal resistance to seismic loads. The braces will be attached to the vault walls by welding the channels to embedded plates in the concrete walls. All structural steel will have protective coating.

The bottom tier canisters will be lowered into the rack system and guided by carbon structural steel angles $2-1 / 2$ in. $x 2-1 / 2$ in. placed around the canister storage port. The canister will be placed on open grating with bearing bars 2 inches deep. After the bottom canister is placed in its storage position, an open grating trap door will be closed above the canister. The top canister will then be lowered into the rack and will be supported by the trap door.

\subsection{Support Structures}

The facility will incorporate a support structure for housing the exhaust portion of the HVAC equipment. This facility will be a steel-framed structure with prefinished metal siding and a built-up roof. Overall dimensions of this enclosure are $80 \mathrm{ft}$ by $70 \mathrm{ft}$. The vault ventilation system is not considered a safety class system, and the support structure is classified as a non-critical facility. The support structure will house four (4) fans, eight (8) HEPA filter units $(30,000$ cfm/unit), and supply and exhaust ducts.

\subsection{Site Work}

Site work includes excavation for the vaults and below grade transfer tunnels, backfilling, grading, and service roads. The reinforced concrete road for the shielded canister transporter between the DWPF and GWSB1 will be extended to the loading area of the proposed GWSB2. Underground utilities such as domestic wate $_{1}$, fire water, and sewer will be extended to the new building from GWSB1. 


\subsection{MECHANICAL EQUIPMENT}

\subsection{Bridge Crane}

The remotely operated bridge crane consists of a single bridge with two hooks and two hoists, one 20-ton hoist and one 3-ton hoist. The crane will have a bridge span of $50 \mathrm{ft}$. The crane runway rails will extend from the loading and unloading area to the far end of the storage vault (a horizontal travel distance of $240 \mathrm{ft}$ ). The height from the top of the crane rail to the lower-tier canisters is approximately $27 \mathrm{ft}$. The crane system will be fully automated with indexing controls and will be used to store and retrieve canisters. The crane system will be operated remotely from a control room in the facility loading area.

The crane will handle canisters that are $9 \mathrm{ft}-10$ inches long, 24 inches in diameter, and weigh about $4,800 \mathrm{lb}$. In addition to handling canisters, the crane is expected to handle shield plugs and blocks weighing about 6 tons. The crane will have two hooks and two hoist motors, one for each type of loading. The remotely operated crane will lift a canister and place the canister in a predetermined position. In addition to the automated posicioning system, the crane system will include:

- Three on-bridge video cameras and lighting for yiewing of the work area and to allow the operator to assist in canister placement and retrieval (CCTV cameras will be monitored from the control room)

- A passive failed bridge recovery mechanism, which will allow the operator to return the crane to the service area in the event of a bridge drive failure

- An emergency system for lowering of a glass canister in the event of a hoist failure

- A manipulator arm to close the trap doors above the lower tier canisters in each of the 1,134 storage positions

- Monitoring equipment to display the cranes position in the control room. Controls mounted on the crane will be minimized because the crane will operate in a relatively high-gamma radiation field 
The facility loading area will include a crane maintenance and repair area. This is a manned entry area with a shield door.

\subsection{Transfer Tunnel Cars}

Two transfer tunnels with cars will be used to transfer canisters between the transporter bay and the vault area. Each tunnel has an entry plug and an exit hatch that can be removed. The entry plug is removed by the transporter when loading a new canister. The crane can handle the exit hatch, which will normally be left open. The exit hatch can be closed to permit manual maintenance of the transfer tunnel. The equipment in each tunnel includes: a canister transfer car; two drive systems and motor controls for each transfer car; a transfer car recovery system; CCTV cameras, lighting, and instrumentation for monitoring transfer car operations.

The transfer cars will be in shielded tunnels as shown in Figures 4 and 5. Each car will have two basic positions. The two positions include: (1) a position for receiving the canister from the transporter; and (2) a position for lifting the canister with the bridge crane. The transfer cars are expected to travel about 25 feet horizontally. The cars will be equipped with a funnel to allow a canister that is aligned to within 6 inches of center to be lowered into the car. All surface areas that are in contact with the canister shall be stainless steel. Each car will be equipped with two drive systems that operate independently. Each transfer car will have an emergency retrieval system. The emergency retrieval system will allow recovery and positioning of the car under one of the openings in the case of drive failure. The empty canister transfer cars are designed for contact maintenance. The transfer cars can also be lifted out of the tunnels through openings in the tunnel roof (floor of transporter bay) for replacement.

\subsection{Vault Cooling System}

The vault is serviced by a mechanically induced air cooling system. The air cooling system removes the decay heat, prevents devitrification of the glass (preclude glass temperature from exceeding $824^{\circ} \mathrm{F}$ ), and prevents the temperature of the concrete from exceeding $150^{\circ} \mathrm{F}$. The combined heat generation rate of the 2,268 canisters in the vault is estimated at $1,520 \mathrm{~kW}$ $\left(5.18 \times 10^{6} \mathrm{Btu} /\right.$ hour $)$. This rate is based on a decay heat source of 670 watts per canister. Cooling air will enter the vault area near the floor by air inlet shafts on the side of the building (see Figures 1,3, and 6). A duct system below 
the canisters will distribute the air throughout the vault and will ensure a balanced distribution. Subsequently, the air passes between the canisters and flows upward. The axial airflow cools the canisters and leaves the compartment through air outlet shafts near the roof slab. There is one inlet and one outlet shaft for each compartment. If there is indication that the exhaust air bears radioactive contamination, the air can be passed through HEPA filters before discharge to the atmosphere.

The HVAC system includes both supply and exhaust systems. The supply subsystem will supply $165,000 \mathrm{cfm}$ of air, and includes four supply fans with a $1 / 3$ capacity each and with rough-in filters and dampers. Each fan will supply $55,000 \mathrm{cfm}$ of air. Three of the fans will operate continuously and one will serve as a standby unit. The exhaust subsystem consists of four $1 / 3$ capacity units. Each unit will have a capacity of $60,000 \mathrm{cfm}$. Each unit will consist of one fan with a capacity of $60,000 \mathrm{cfm}$ and two HEPA filtration subunits of $30,000 \mathrm{cfm}$ capacity per unit. Normally, the exhaust air will bypass the filtration units and will be released to the atmosphere. However, if radiation is detected by area radiation monitors, the exhaust air will be routed through the filtration units. Radiation monitors located downstream of the exhaust fans will provide continuous exhaust air monitoring.

The exhaust subsystem will be housed in the support structure. The ventilation system can be operated with standby power from the DWPF emergency power source to ensure continuous airflow. The ventilation system is not considered a safety class system (a failure of the ventilation system cannot immediately cause structural failure). Based on information presented in the $\mathrm{FDC}^{2}$, it will take several days of system inoperability and vault heatup following system failure for structural damage to occur. The time span will allow the operator to intervene and to restore airflow through the vault. The ventilation system can also be designed for natural convection cooling.

\subsection{ELECTRICAL AND CONTROL EQUIPMENT}

\subsection{Electrical Requirements}

Electrical requirements will incorporate the following:

- One $13.8 \mathrm{KV}-480 \mathrm{~V}$ substation located outside the GWSB

- One $480 \mathrm{~V}$ motor control center (MCC) located in the control room 
- Control cabinet for the overhead bridge crane

- Lighting panel(s) located in the control room

\subsection{Instrumentation and Control System Requirements}

Instrumentation and control requirements are as follows:

- Radiation monitoring system cabinet located in the control room

- Fire detection system cabinet located in the control room

- Public address system cabinet located in the control room

- Digital control system

- CCTV operating console

- HVAC control cabinet

\subsection{FACILITY OPERATION}

The existing shielded canister transporter (SCT) will transfer canisters from DWPF to the loading bay of GWSB2. The SCT is a large rubber-tired transporter that incorporates a shielded cask, a floor plug, and associated lifting and positioning equipment. The SCT will pick up the canister in the load out area of Building 221-S and will drive to the loading bay of the proposed GWSB2. Once inside the transporter bay, the SCT driver will position the plug hoist over one of two entry plugs in the bay floor (depending on the tunnel selected). Lifting the entry plug and lowering the glass canisters from the SCT shield cask into the transfer tunnels is an operation similar to placing a canister in storage in GWSB1. Following this operation, the SCT will leave the loading bay. The canister transfer car will move the canister from the entrance location in the tunnel to the transfer port on the vault's side. On the transfer port side, the canister is in a position accessible by the bridge crane which serves the vault. All subsequent storage and retrieval operations will be carried out remotely with the bridge crane. Each of the transfer tunnels is provided with closed circuit video cameras and lights to observe all remote operations.

The crane will normally be parked in the crane maintenance room (a radiation free area). This is to protect the crane conductors and control electronics from radiation damage when the crane is not in use. The crane maintenance room is a radiation free area in the loading structure (Figure 4). This operation is necessary because the vault radiation doses at the bridge level will be significant. If the crane was left in the vault area when not in use, the crane 
control electronics will experience high integrated doses. A shield door will separate the crane maintenance room from the vault and will permit manual crane maintenance and repair.

\subsection{PROJECT CLASSIFICATION}

From a design classification standpoint, the proposed glass waste storage facility is classified as a critical protection facility. With respect to the hazard classification, the facility is classified as a nuclear facility. The facility hazard classification is assumed to be similar to the classification of the reference FDC facility, which has an overall Facility Hazard Classification of moderate hazard. Similarly, the loading area segment of the facility ha: : Facility Segment Use Category of low hazard.

\subsection{SCHEDULE}

This project is planned for completion in 1999 or 2000. This clate is projected to coincide with the filling of GWSB1 to its design capacity and the need for additional canister storage space. Assuming a construction period of three years, construction will need to start in 1996 to meet the 1999 project close-out date.

\subsection{PROJECT INTERFACES}

\subsection{Glass Canisters}

The glass canisters are cylindrical and are shaped like bottles. The canisters are 24 inch in diameter, 118 inches high, and are made of stainless steel with walls that are 3/8-inch thick. Gross weight of the filled canisters is $4,800 \mathrm{lb}^{5}$. Each canister has an average decay heat source of 670 watts and may contain a maximum activity of 230,000 curies, $24 \%$ of this activity $(55,000$ Curies) is due to Cesium-137. All canisters will be fully sealed and decontaminated before transport to GWSB2.

\subsection{Shielded Canister Transporter}

The SCT is a rubber-tired transporter designed to transfer canisters containing high-level waste from Building $221-\mathrm{S}$ to the temporary storage building. The SCT is approximately 24 feet wide $x 25$ feet 6 inches long. The SCT has a maximum height of $18 \mathrm{ft} 5.5$ inches $^{5}$. The overall weight of the transporter is 
$260,000 \mathrm{lb}$. The glass cylinders are carried in a tall cylindrical housing in the center of the transporter.

\subsection{COST ESTIMATE}

The Project Management Department of Engineering and Projects Division (E\&PD) completed a detailed cost estimate for the proposed design 6 . The labor, materials, and engineered equipment were priced using the same rates as the June 1991 estimate for the reference $F D C / C D R$ facility ${ }^{7}$. A summary of the estimate is presented in Table 9.1. Total dirent costs of the proposed facility are \$7.1 million. Table 9.1 also provides the cost estimate for the FDC/CDR facility. Total direct costs of the conceptual design facility are $\$ 31.2$ million (1991 rates). These costs imply potential savings of $\$ 24$ million in direct costs and additional savings in indirect costs such as contract services, engineering, and management. The cost estimate confirms the findings of the preliminary cost assessment of October $1991^{3}$.

\begin{tabular}{|c|c|c|c|}
\hline $\begin{array}{l}\text { Direct } \\
\text { Design an }\end{array}$ & 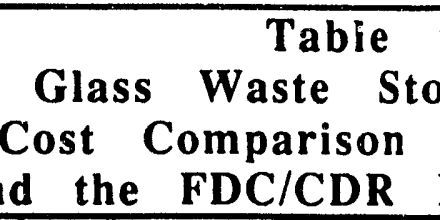 & $\begin{array}{l}.1 \\
\text { rage Facility } \\
\text { Between the Prol } \\
\text { Design (June } 1991\end{array}$ & $\begin{array}{l}\text { osed } \\
\text { rates) }\end{array}$ \\
\hline Item Description & $\begin{array}{c}\text { Alternative Design } \\
\text { Concept }\end{array}$ & $\begin{array}{c}\text { FDC/CDR Design } \\
1991 \text { BNI Estimate } \\
\end{array}$ & $\begin{array}{c}\text { Cost Difference } \\
\text { (Percent)* }\end{array}$ \\
\hline Labor Cost & $\$ 1,928,000$ & $\$ 14,189,000$ & $+636 \%$ \\
\hline $\begin{array}{l}\text { Engineered } \\
\text { Equipment }\end{array}$ & $\$ 416,000$ & $\$ 3,306,000$ & $+695 \%$ \\
\hline Bulk Materials & $\$ 3,326,000$ & $\$ 12,700,000$ & $+282 \%$ \\
\hline Contract Services & $\$ 1,387,000$ & $\$ 966,000$ & $-30 \%$ \\
\hline TOTAL & $\$ 7,057,000$ & $\$ 31,160,000$ & $+341 \%$ \\
\hline
\end{tabular}

* Indicates percent cost difference of FDC/CDR facility relative to the alternative design facility. A plus sign (+) implies a higher cost for FDC/CDR facility.

The June 1991 cost estimate included the cost of two emergency diesel generators and support structures for housing the generators. The cost of the 
emergency generators, ancillary equipment, and support structures is estimated at \$1.2 million. The alternative design does not include emergency generators because, based on the revised $\mathrm{FDC}^{2}$ emergency power can be obtained from the DWPF. The elimination of diesel generators dedicated to GWSB2 is not unique to the alternative design and this cost could also be deducted from the CDR estimate. Eliminating diesel generators from the $\operatorname{CDR}$ cost estimate ${ }^{7}$ will reduce direct costs by approximately $\$ 1.2$ million and result in a total direct cost of $\$ 30$ million ( $\$ 31.2$ million minus $\$ 1.2$ million) for the June 91 estimate. Even when we account for the reduced savings explained above there is still the potential of saving $\$ 22.8$ million in direct cost by opting for the alternative design.

The June 1991 estimate is of a significantly higher quality than the preconceptual scope prepared for the proposed alternative. The June 1991 estimate was based on a fully developed CDR, while the estimated cost for the alternative design is based on the scope outlined in this report, which is not as well developed as the CDR. In view of the large cost disparity between the two concepts, accounting for this will not change the overall conclusions of the cost comparison. The proposed alternative remains the more cost-effective option.

\subsection{ASSESSMENT OF THE PROPOSED STORAGE SCHEME}

Advantages of the proposed design as compared with the CDR design are defined below.

- A more effective vault structure and improved utilization of vault storage space. In the proposed design, about $20 \%$ of the vault volume is utilized for glass storage compared to only $12 \%$ for the CDR design. The proposed design calls for only 6,500 cubic yards of reinforced concrete vs. approximately 28,000 cubic yards for the CDR design. This increased capacity results in a more cost-effective storage scheme with the potential of saving $\$ 23$ million in direct costs alone.

- A simplified design with improved constructability. Of special importance is eliminating the large shielded operating floor with 2,262 access ports and shield plugs. The operating floor of the FDC/CDR facility is of a composite design and consists of precast concrete panels and a thick concrete slab poured over these panels. The operating floor has to support its deadweight as well as the $260,000 \mathrm{lb}$ of the SCT. By eliminating the operating floor, significant savings can be realized. 
- Because the proposed vault is self-enclosed the column-free operating area enclosure (OAE) in the FDC/CDR is no longer required. The OAE is a steelframed structure with prefinished metal siding and measures $207 \mathrm{ft} \times 184 \mathrm{ft}$ x 37 feet. Eliminating shis structure is an additional source of cost savings.

- The proposed facility will require about $60 \%$ less real estate (land resources) than the FDC/CDR facility.

- The proposed facility design can be readily modified for added storage capacity. This modification can be achieved by adding a compartment or by expanding the size of the thre: compartments included in the base design. The expansion will only affect the vault design and will not have a significant impact on the loading area design. Because the loading equipment and support facilities can be shared, the incremental cost of additional canister storage positions is modest. This does not hold true for the FDC/CDR facility, where additional storage will require new vaults at a unit cost that is almost directly proportional to the unit cost of storing a canister in the original design.

- As a result of the two-tier arrangement and the more compact storage scheme, the proposed design is more compatible with either a forced draft or natural draft cooling arrangement.

- The reference FDC/CDR design and GWSB1 have no provisions for eventually loading canisters into shipping casks for off site transport to a federal repository. This phase will require a new facility specifically dedicated to loading for off site transportation. With the alternative design, provisions for canister load-out can be integrated into the loading area design.

- The alternative design constitutes a more flexible facility that can be converted to other uses when the facility is no longer needed for glass canisters storage. By either deferring the installation of the storage racks in the vault, or by removing the racks, the vault can be used to store other wastes whether it is contact handled or not. This design flexibility is not available in the reference CDR facility.

Items that add to the cost of the alternative design and are not required by the reference FDC/CDR facility are: 
- The remotely operated bridge crane system

- Equipment and facilities such as the loading bay, transfer tunnels, and transfer cars used to transfer canisters from the transporter bay into the vault

- The crane maintenance and repair room

- Equipment for remote operations and monitoring, like control room console, CCTV cameras and manipulator arm

The above items add to the cost of the alternative facility. However, as is evident from the cost estimate, the savings of this design far outweigh the additional cost of the items listed above.

\subsection{SUMMARY}

This report presented a cheaper but equally effective alternative for the storage of vitrified waste canisters at SRS. The proposed facility appears feasible and is compatible with existing methodology for transferring canisters from DWPF to interim storage. The cost estimate that was performed indicates that the alternative has the potential of saving $\$ 23$ million in direct costs alone. The additional work reported herein fully confirms earlier findings 3 concerning the cost effectiveness of the proposed design. 


\section{REFERENCES}

1. Defense Waste Processing Facility Glass Waste Storage Building \#2 Conceptual Design Report, Volumes 1 and 2, Rev. A, April 22, 1991. Prepared by Bechtel National, Inc. Job \#13293.

2. Functional Design Criteria for Project S-2045 Glass Waste Storage Building \#2 (U), WSRC Systems Engineering, Rev. 1, May 19, 1992 (not yet approved by DOE).

3 Westinghouse Savannah River Company, Inter-Office Memorandum from R. Rainisch to S. Pogula, titled: "DWPF Second Glass Waste Storage Building Alternative Design Concept," dated October 18, 1991, EDD-91-1090:41.

4. Westinghouse Savannah River Company, Inter-Office Memorandum from S. Downey to Dan Malizia, titled: "Letter of Instruction \#LOI-S-2045-001 to Systems Engineering for the Glass Waste Storage Building \#2 (S-2045)," dated June 26, 1992, EPD-DWP-92-5005 (DP-92-00-45).

5. E. I. Du Pont De Nemours and Company, Procedure Titled: "Savannah River Plant, DWPF Process and Equipment Description," Rev. 2, dated November 1988, DPSOP 257- 1.

6. Westinghouse Savannah River Company, Inter-Office Memorandum from J. Iwert to R. Rainisch, titled: "Defense Waste Processing Facility Estimate Option Study GWSB2," dated October 5, 1992, EPD-PEC-92-0515.

7. Bechtel Savannah River Site, Memorandum from D. L. Ketcham to G. E. Meek (WSRC Aiken), "Project S-3420 - SRS - 200S Area, Glass Waste Storage Building \#2 (Project S-2045) Conceptual Cost Estimate", dated June 5, 1991. 


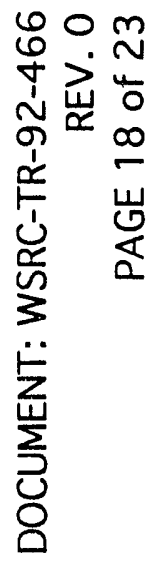
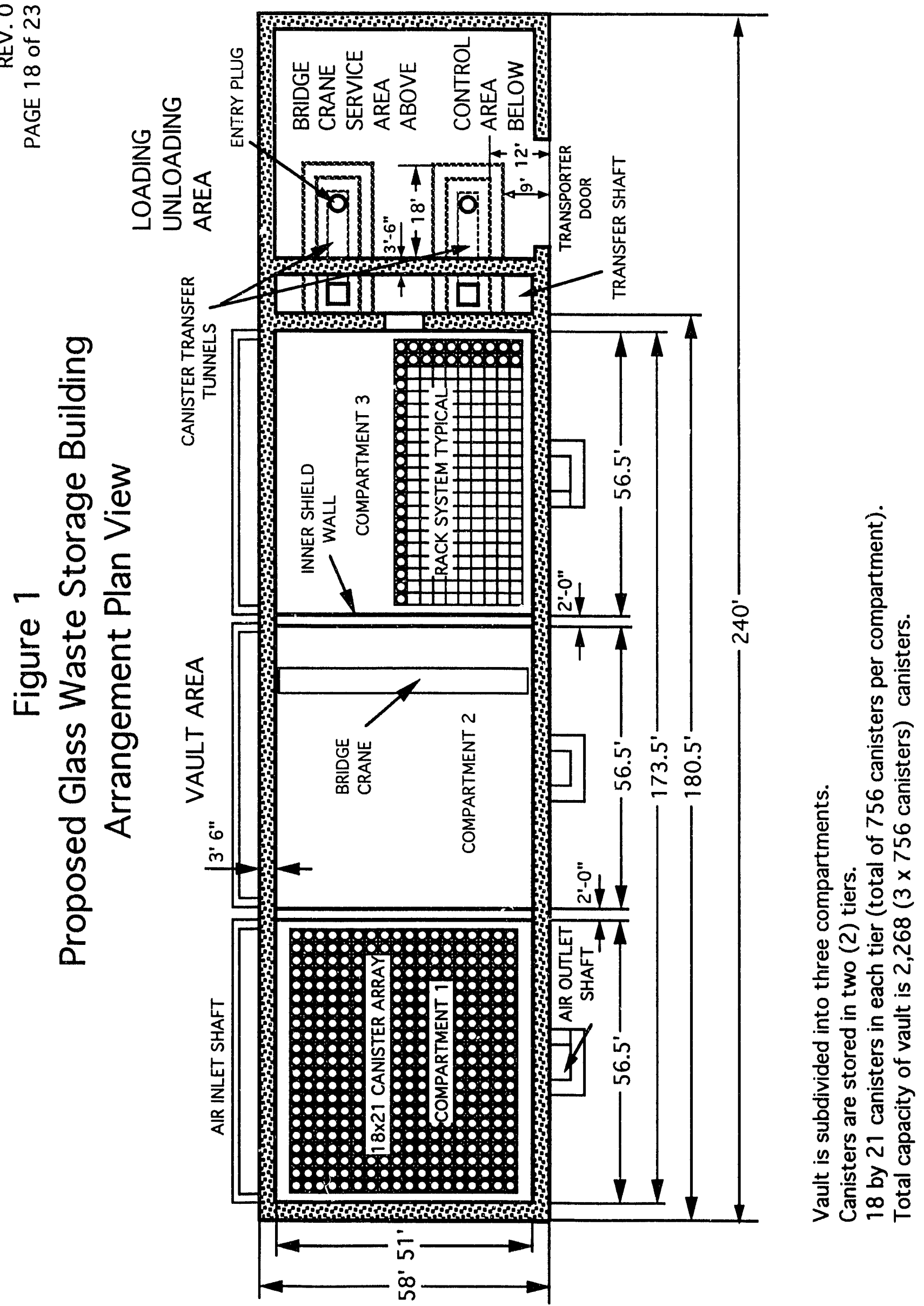


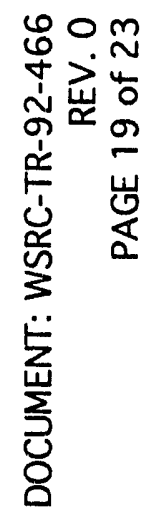

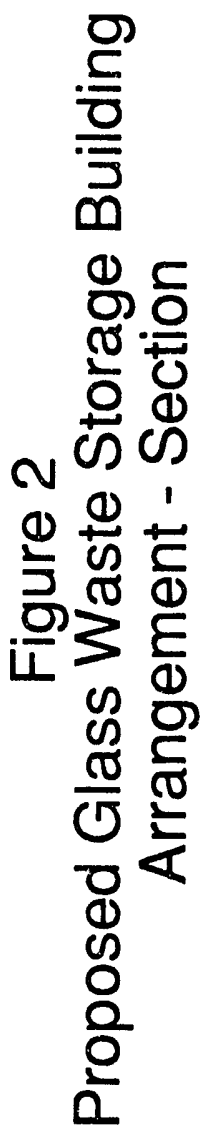

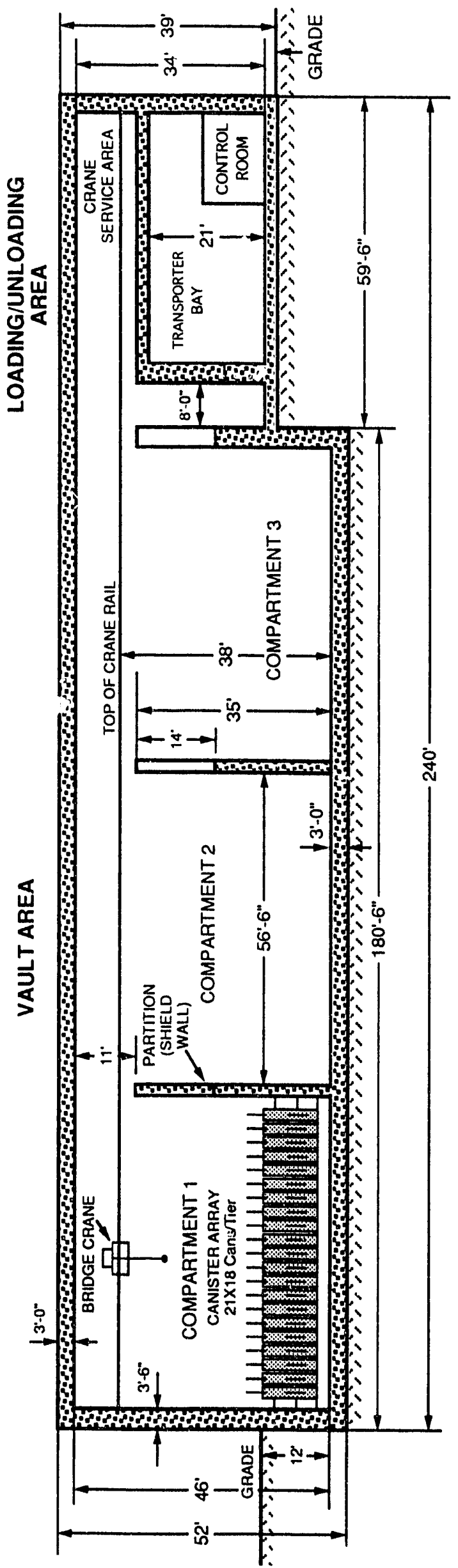



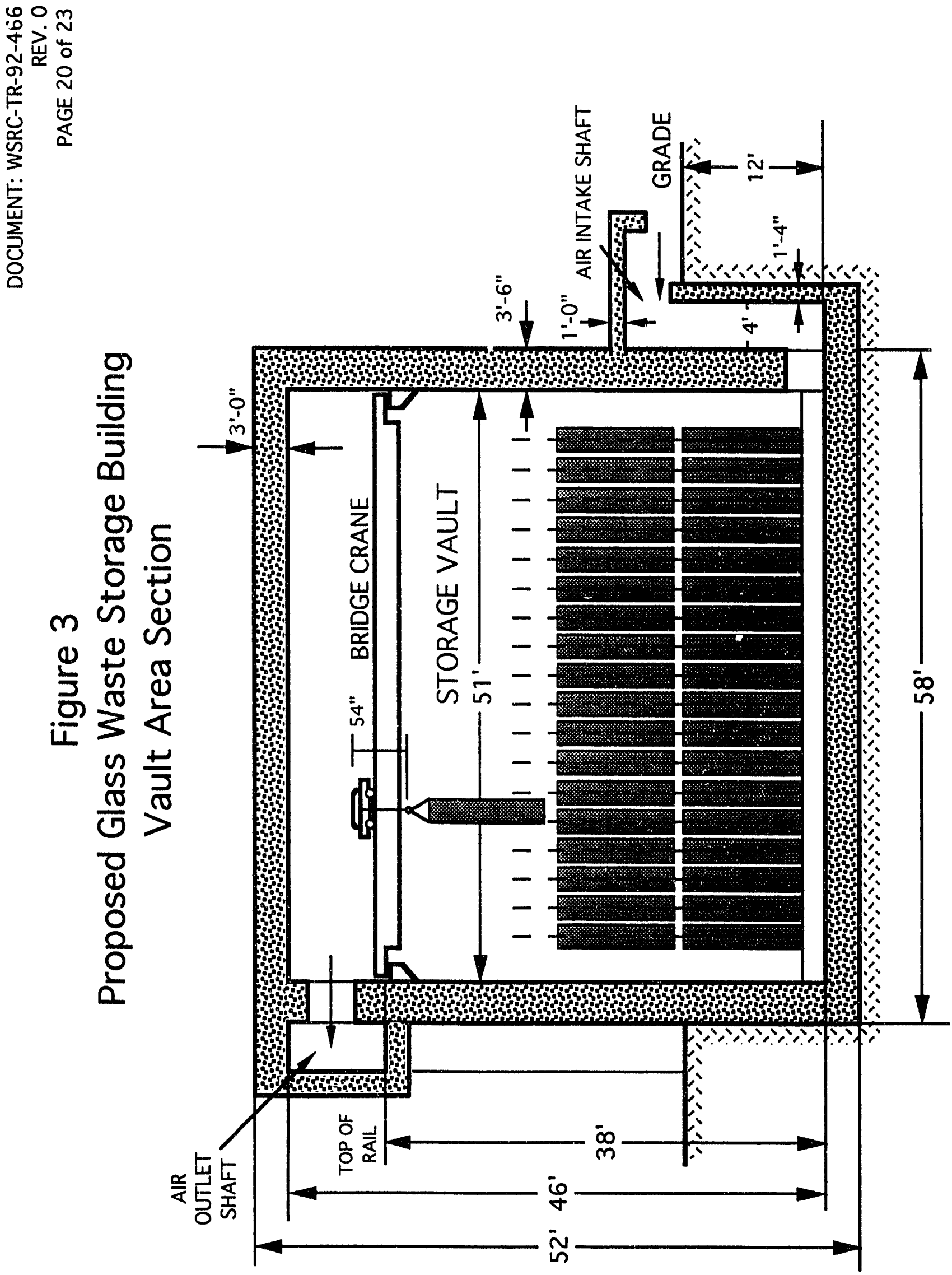

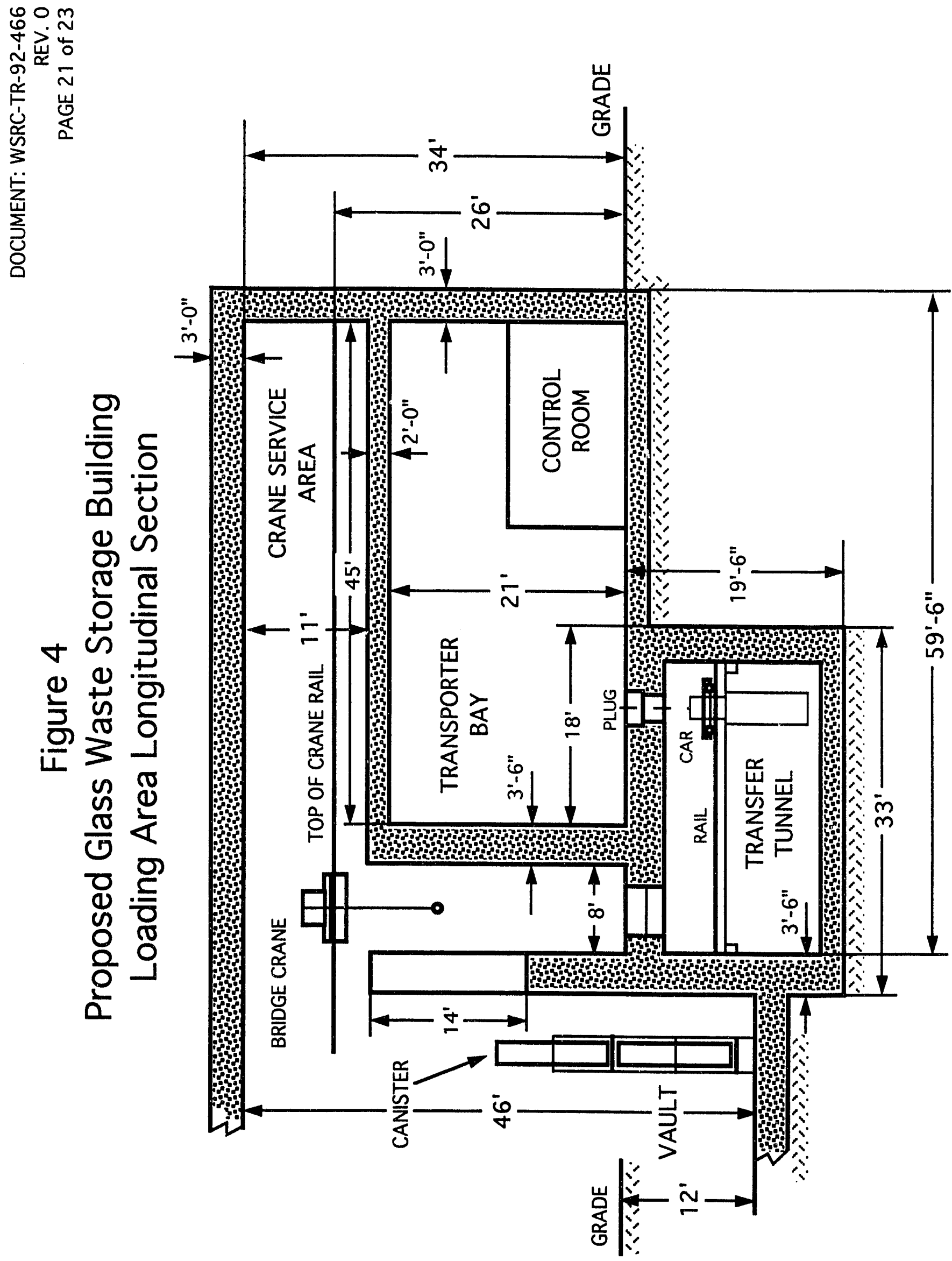


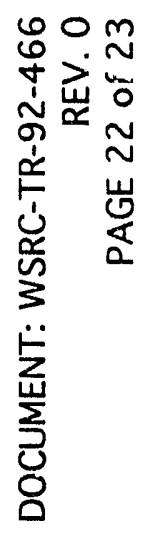
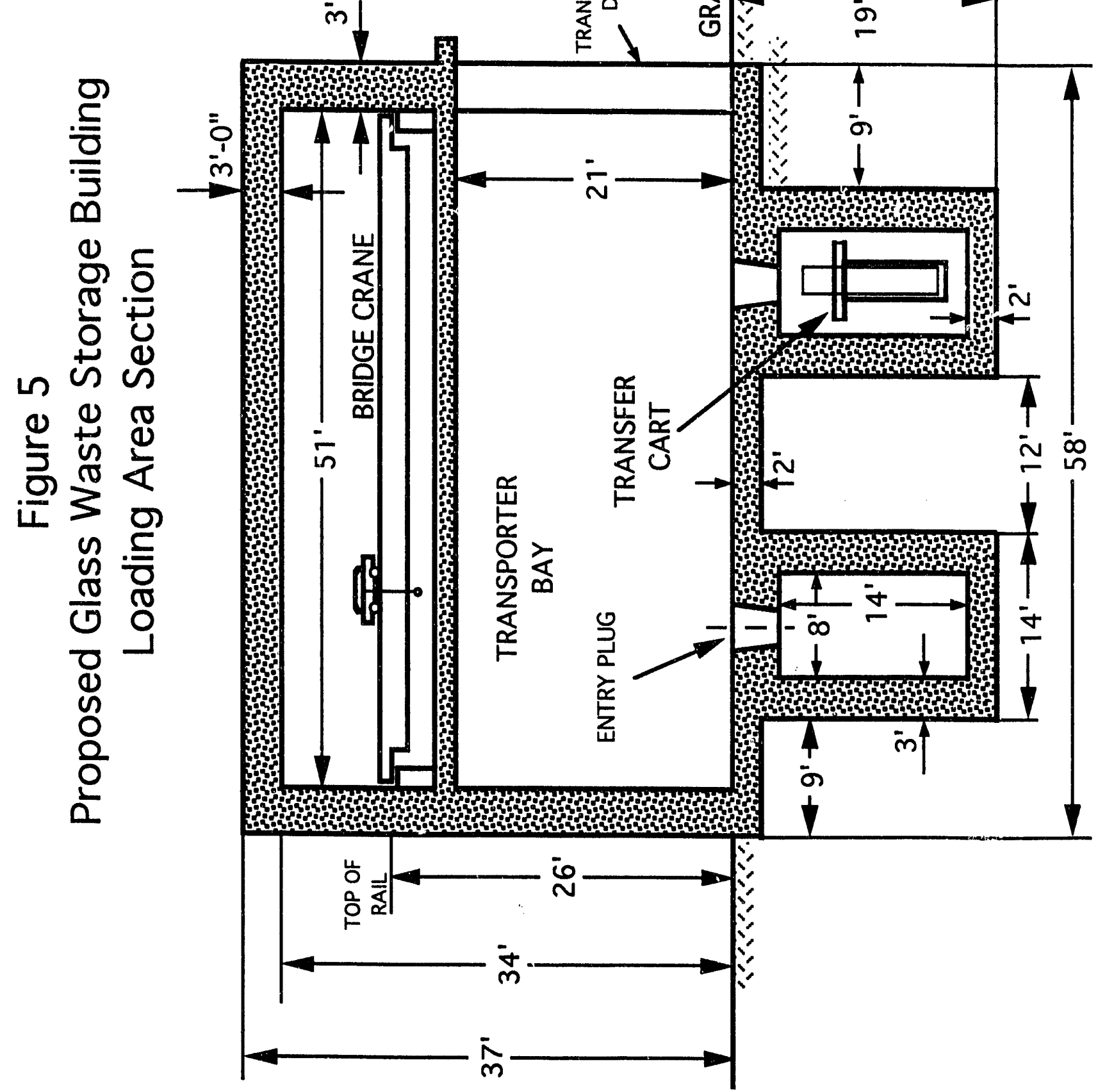


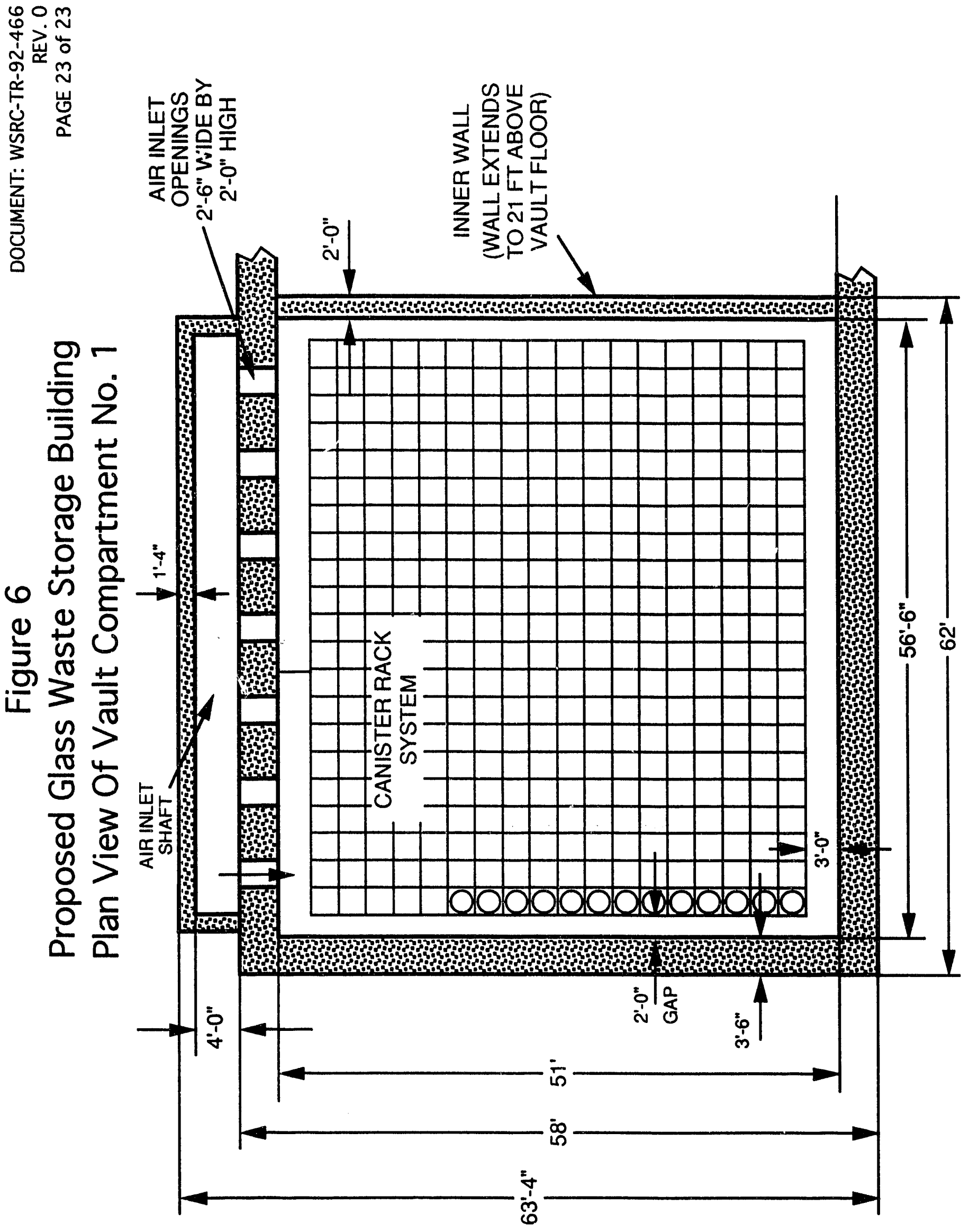


$\nabla$
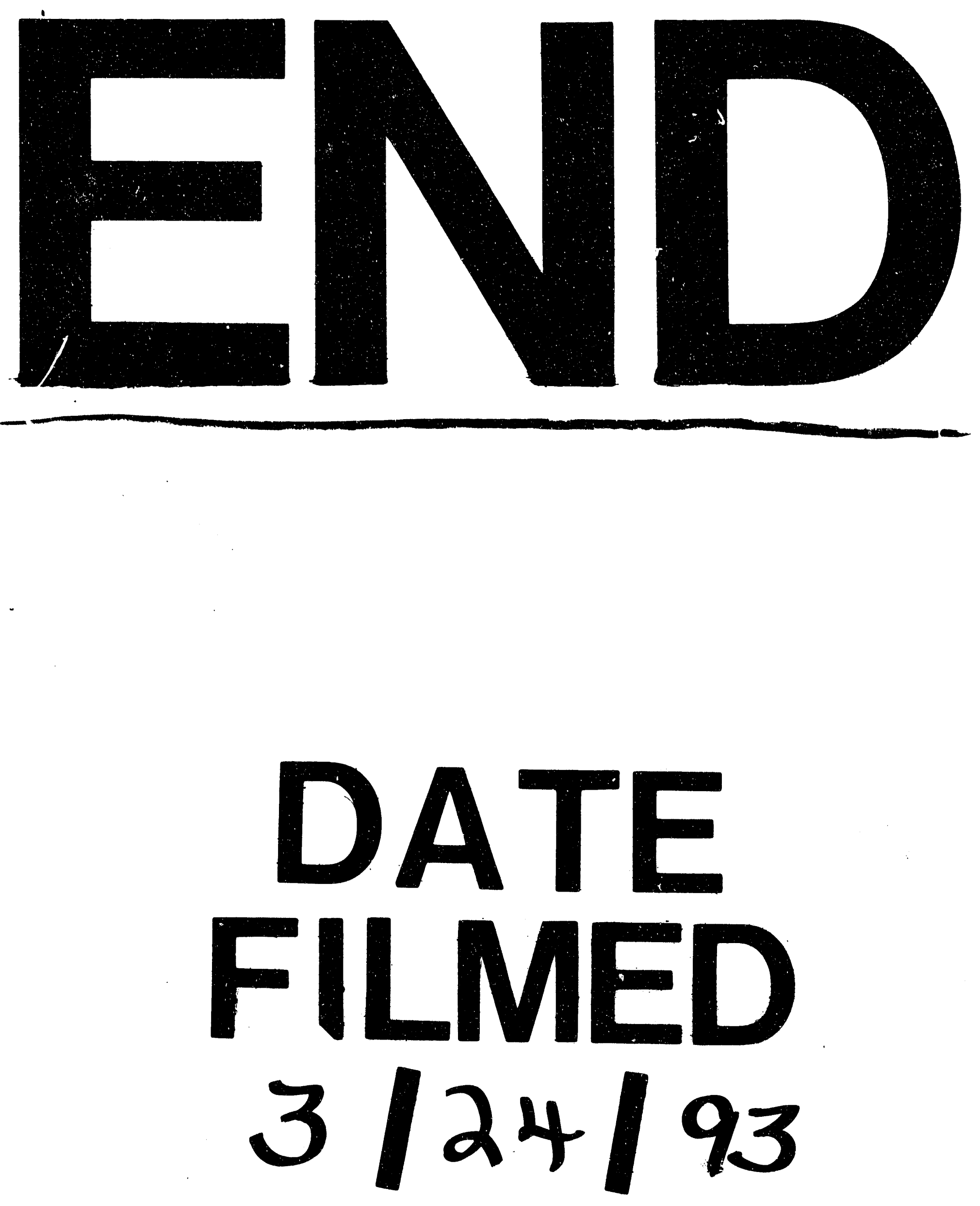